\title{
The Effect of Learning Models and Learning Interest on Students' Mathematics Learning Results on Social Arithmetic Material for Grade 7 Mtsn 3 Langkat
}

\author{
Zulkifli Hasibuan Asmin Sumarno \\ Basic Education, Postgraduate School, State University of Medan \\ Medan, North Sumatra, Indonesia
}

\begin{abstract}
The objectives of this study are (1) to determine the differences in student learning outcomes between the treatment of inquiry learning models and conventional learning models with high learning interest; (2) To determine the difference in student learning outcomes between the treatment of inquiry learning models and conventional learning models with low learning interest; (3) To determine the interaction of the learning model on learning outcomes and student interest in learning. This research is classified as a quasi-experimental research. This research will be conducted at MTSN 3 Langkat. The population in this study were all seventh grade students at MTSN 3 Langkat Terpadu Medan in the 2021/2022 academic year. From the research findings, it was found that for mathematics learning outcomes towards high interest in learning, a significant value of learning outcomes on high learning interest was $0.003<0.05$, for mathematics learning outcomes to low interest in learning, a significant value of learning outcomes on low learning interest was $0.431>0.05$ and for the results learning mathematics based on interest in learning with class teaching has a sig. $0.027<0.05$ which means that there is an interaction between the two. This means that there is an interaction between the inquiry learning model and direct learning with interest in learning that is applied simultaneously affecting learning outcomes.
\end{abstract}

Keywords: learning model, math learning result, interest learning, social arithmetic

DOI: $10.7176 / \mathrm{JEP} / 12-33-13$

Publication date: November $30^{\text {th }} 2021$

To improve Indonesia's human development index, we need a material that is taught and studied at every level from elementary school to university, namely mathematics. Mathematics is a universal science that underlies the development of technology and has an important role in various disciplines and advances the power of human thought. Hasratuddin (2018: 159) argues that mathematics is a product of human intellectual thinking. Intellectual thinking is usually driven from problems involving real everyday life. In this way mathematics is also called human life and a means to train thinking. It turns out that not only that, Eviliasani, Hendriana and Sanjayawati (2018: 334) that mathematics is taught basically aims at the mindset of students so that they can solve problems and are creative, critical, logical, analytical, systematic, and have the ability to work together.

But in fact, according to Rahmawati (2014: 75) explains that the low achievement of student learning outcomes in mathematics has not been very satisfactory both at the National and International levels. The low learning outcomes of Indonesian students at the international level are still lagging behind compared to other countries. It can be seen from the results of the World Competitiveness Year Book survey, Indonesia is at level 37 out of 60 countries. Similar conditions can be seen from the results of studies conducted by the Program For International Student Assessment (PISA) and Trends International Mathematics and Science Study (TIMSS).

The low learning outcomes and mathematical abilities are caused by the fact that there are still many students who have difficulty in learning mathematics, are less interested, and always regard mathematics as a difficult subject, thus creating a fear of learning mathematics. Abdurrahman (2009: 252) reveals: Of the various fields of study taught in schools, mathematics is the field of study that is considered the most difficult by students, both those without learning difficulties, and more so for students with learning difficulties.

But in reality, the results of learning mathematics on mathematics learning are still low. It can be seen from the results of Atun's research (2006) that the pre-test for the test of mathematics learning outcomes in the experimental class reached an average of 25.84 or $33.56 \%$ of the ideal score. Likewise, the results of Agustina's research (2011) revealed that the pre-test for the ability to test the learning outcomes of 32 students, only 18 students who finished studying or $56.25 \%$ of the total number of students.

Students' interest in learning is the main factor that determines the degree of student learning activity. Usman (2005:27) suggests that in essence children have an interest in learning. Shalahudin (1990:95) states interest as attention that contains elements of feelings. Therefore, interest greatly determines the attitude that causes someone to be active in a job or situation or in other words, interest can be the cause or motivational factor of a student activity.

To have the ability to learn mathematics and good interest in learning in a lesson is not easy, but 
mathematical abilities can be learned and trained. Therefore, teachers must find learning that can involve students in solving mathematics. There are many learning models that can be used in an effort to develop learning outcomes and interest in learning mathematics. One of the learning models that is expected to be in line with the characteristics of mathematics and the expectations of the current curriculum is the inquiry learning model.

The inquiry learning model is a series of learning activities that emphasize critical and analytical thinking processes to seek and find answers to a problem that is being questioned by Hamdayana (2016:132). The inquiry learning model is a model that emphasizes the intellectual development of students.

The inquiry learning model must meet four criteria, namely clarity, suitability, accuracy and complexity. Students are really placed as the subject of learning. The teacher's role in learning with the inquiry learning model is as a guide and facilitator. The teacher's job is to choose a problem that needs to be presented to the class to be solved. However, it is also possible that the problem to be solved is chosen by the student. The next task of the teacher is to provide learning resources for students in order to solve problems. Teacher guidance and supervision is still needed, but intervention on student activities in problem solving must be reduced.

The inquiry learning model that is applied must pay attention to the steps. Because then, various advantages that exist in the inquiry learning model can be obtained. The advantages of the inquiry learning model include; emphasizes the development of cognitive, affective, and psychomotor aspects in a balanced way so that learning with this strategy is considered more meaningful, can provide space for students to learn according to their learning style, is a strategy that is considered in accordance with the development of modern learning psychology which considers learning as a process of change behavior due to experience, and can serve the needs of students who have above average abilities. Based on the problems above, researchers are interested in conducting research on "The Influence of Inquiry Learning Models and Learning Interests on Mathematics Learning Outcomes of Social Arithmetic Materials for Class VII MTSN 3 Langkat Students".

\section{LITERATURE REVIEW}

\section{Inquiry Learning Model}

The inquiry model is a learning model that focuses on student activities in the learning process. Learning with the inquiry model was first developed by Richard Suchman in 1962 (Joyce, 2000). He wants students to ask why an event occurs, then he teaches students about procedures and uses the organization of knowledge and general principles. Students carry out activities, collect and analyze data, until finally students find the answer to the question.

The inquiry model means a series of learning activities that maximally involve all students' abilities to search and investigate systematically, critically, logically, analytically, so that students can formulate their own findings confidently (Gulo, 2002:84).

The inquiry model is defined by Piaget (Sund and Trowbridge, 1973) as: Learning that prepares situations for children to experiment on their own; in a broad sense wanting to see what happened, wanting to do something, wanting to use symbols and looking for answers to their own questions, connecting one discovery to another, comparing what was found with what others found.

Kuslan Stone (Dahar, 1991) defines the inquiry model as teaching in which teachers and children study scientific events and phenomena with the approach and spirit of scientists. Inquiry-based teaching is a studentcentered strategy in which groups of students are faced with a problem or seek answers to questions in a clearly outlined procedure and group structure (Hamalik, 2005).

\section{Direct Instruction}

Informal and procedural knowledge that leads to basic skills will be more effective if delivered by Direct Instruction. According to Sanjaya (2006:47) the characteristics of direct learning (direct instruction) are learning that emphasizes the verbal delivery process from a teacher to a group of students with the intention that students can master the subject matter optimally. The center of the lesson is the teacher, students listen and take notes as necessary, communication occurs in one direction, and generalizes students' academic abilities. Direct learning method (direct instruction) is a learning method that places the teacher's position as the main regulator of student teaching and learning activities. This learning method takes place in one direction, the teacher provides ideas or information and students receive it.

\section{Learning Interest}

The success or failure of a person's activity is influenced by the growth of interest in a person so as to provide encouragement for that person to carry out certain activities in order to achieve goals. This tendency to like something compared to others is called interest. A positive initial attitude in the form of liking from students also determines the success of the learning process carried out.

The higher the passion or desire for something is the first step towards further success. A person's interest in 
an object will bring a tendency to get closer to the object of interest. and teachers themselves should try to arouse children's interest in learning. Learning is a process of adaptation or adjustment of behavior that takes place progressively which, if given reinforcement (reinforcement) can bring an optimal result. Learning can also be interpreted as a relatively permanent change in behavior as a result of training and experience.

\section{METHOD}

\section{Research design}

This type of research is classified as a quasi-experimental research (quasi-experimental). This study uses a quasiexperimental method with existing classes. The purpose of this study was to see the effect of the inquiry learning model and interest in learning on learning outcomes. This study took two parallel classes randomly representative of the population by applying different learning. The first class was treated by applying inquiry learning and the second class was given treatment by applying direct instruction learning. This research was conducted to determine the test of learning outcomes and interest in learning between students who received learning with inquiry learning in the experimental class and students who received conventional learning in the control class.

Table 1. Research Design

\begin{tabular}{|c|c|c|c|}
\hline Class & Pretest & Treatment & Post- test \\
\hline $\begin{array}{c}\text { Experiment } \\
\text { (inquiry) }\end{array}$ & $\mathrm{T}_{1}$ & $\mathrm{X}_{1}$ & $\mathrm{~T}_{2}$ \\
\hline $\begin{array}{c}\text { Control } \\
\text { (Direct Instruction) }\end{array}$ & $\mathrm{T}_{1}$ & $\mathrm{X}_{2}$ & $\mathrm{~T}_{2}$ \\
\hline
\end{tabular}

Information:

$\mathrm{X}_{1} \quad$ : Learning by Inquiry

$\mathrm{X}_{2} \quad$ : Learning with Direct Instruction

In the design, the experimental group was given learning treatment with inquiry and the control group was given learning treatment with direct instruction, each group was given a pretest and post-test.

\section{Research Instruments}

The instruments used in this study were tests and non-tests. Instrument type test involves pretest and post-test. All types of tests carried out involve a mathematics test in the form of a description test and an open test, while the non-test instrument includes a student learning interest questionnaire and Student Worksheets in the inquiry learning process and direct instruction.

\section{1) Mathematics Learning Outcomes Test}

The benchmarked test is set to measure how far each student can achieve the competencies that have been formulated. The test of mathematics learning outcomes is arranged in the form of a description of 4 questions. Mathematics learning outcomes test was made to measure the ability of class VII students. The answer process in solving the given problem is reviewed from several things, namely: (1) in terms of student errors in solving the given mathematical problem; (2) in terms of the steps used by students in solving the given mathematical problems; (3) in terms of the suitability of the student's answer process with the indicators. The student's answer process was analyzed for each category of assessment.

The scoring guideline was adapted from Facione (Normaya, 2015:93) which consists of four indicators of critical thinking ability as well as descriptions and scores for their acquisition.

Table 2. Mathematics Learning Outcomes Test

\begin{tabular}{|l|c|c|c|c|l|l|}
\hline \multicolumn{1}{|c|}{ Indicators of Achievement of Learning } & C1 & C2 & C3 & C4 & $\begin{array}{c}\text { Question } \\
\text { form }\end{array}$ & $\begin{array}{c}\text { Question } \\
\text { Number }\end{array}$ \\
\hline Understanding mathematical models & $\mathrm{v}$ & $\mathrm{V}$ & $\mathrm{V}$ & $\mathrm{V}$ & Description & $1,2,3,4$ \\
\hline Planning contextual problems & $\mathrm{v}$ & $\mathrm{V}$ & $\mathrm{V}$ & $\mathrm{V}$ & Description & $1,2,3,4$ \\
\hline Solving contextual problems & $\mathrm{v}$ & $\mathrm{V}$ & $\mathrm{V}$ & $\mathrm{V}$ & Description & $1,2,3,4$ \\
\hline Evaluating contextual problems & $\mathrm{v}$ & $\mathrm{V}$ & $\mathrm{V}$ & $\mathrm{V}$ & Description & $1,2,3,4$ \\
\hline
\end{tabular}

2) Questionnaire of Learning Interests

The learning interest scale consists of 4 response categories, namely strongly agree, agree, disagree, strongly disagree. 
Table 3. Independent Questionnaire Grid for Students' Mathematics Learning

\begin{tabular}{|c|l|}
\hline \multicolumn{1}{|c|}{ Indicator } & \multicolumn{1}{c|}{ Information } \\
\hline \multirow{2}{*}{ Feeling happy } & Student opinion about learning mathematics \\
\cline { 2 - 2 } & Student's impression of math teacher \\
\cline { 2 - 2 } & Students' feelings during mathematics learning \\
\hline Attention & Attention when following math lessons \\
\cline { 2 - 2 } & Attention of students when discussing math lessons \\
\hline Participate & Curiosity of students when participating in mathematics learning \\
\cline { 2 - 2 } & Acceptance of students when given assignments / homework by the teacher \\
\hline Student involvement & Awareness about studying at home \\
\cline { 2 - 2 } & Student activities after and before entering school \\
\hline
\end{tabular}

\section{Research Subjects and Objects}

This research will be conducted at MTSN 3 Langkat. The population in this study were all seventh grade students at MTSN 3 Langkat Terpadu Medan in the 2021/2022 academic year. The samples in this study were 2 classes of students in class VII-A as many as 20 students in the control class using the direct instruction model and 20 students in class VII-B using the experimental class 2 using the inquiry learning model.

\section{Data Analysis Technique}

In this study, the analysis used is quantitative (inferential) analysis. In the early stages, data processing begins with descriptive analysis, namely calculating the average, standard deviation, maximum and minimum values of the initial mathematical ability test data, mathematical learning outcomes tests and student interest in learning. The second stage of posttest data is tested using the analysis prerequisite test, the third stage is hypothesis testing.

\section{RESULTS AND DISCUSSION}

\section{a) Mathematics Learning Outcomes at High Learning Interest}

For mathematics learning outcomes on high interest in learning, a significant value of learning outcomes on high learning interest is $0.003<0.05$, it can be concluded that at the $95 \%$ confidence level, learning outcomes are influenced by high interest in learning.

It means that it can be concluded that there are differences in mathematics learning outcomes between students who are given the inquiry learning model and direct learning on high learning interest on the subject of social arithmetic.

\section{b) Mathematics Learning Outcomes at Low Learning Interest}

For mathematics learning outcomes on low interest in learning, there is a significant value of learning outcomes on low interest in learning $0.431>0.05$, it can be concluded that at the $95 \%$ confidence level, learning outcomes are not influenced by low interest in learning.

It means that it can be concluded that there is no difference in mathematics learning outcomes between students who are given the inquiry learning model and direct learning on high learning interest on the subject of social arithmetic.

\section{c) Calculation of Mathematics Learning Outcomes Based on Learning Models and Learning Interests}

For the calculation of mathematics learning outcomes based on learning interest between the control class and the experimental class, a significant value of $0.027<0.05$ was obtained. Meanwhile, the results of learning mathematics based on interest in learning with teaching classes have sig. $0.027<0.05$ which means that there is an interaction between the two. The interaction in this study is the collaboration between learning models and learning interests that are applied simultaneously to affect student learning outcomes.

\section{d) Student Mathematics Learning Outcomes}

The mathematics learning outcomes of seventh grade junior high school students varied. Based on the results of the analysis, the results showed that the average of 20 students in the control class was 74 and 80 in the experimental class. From the test results, it was found that the average student learning outcomes in the control class were lower than those in the experimental class. This means that the inquiry learning model is better than direct learning. It can be seen that there is a significant difference and a tendency for higher results between learning outcomes in the experimental class and the control class. This can be caused by differences in cognitive levels and learning approaches used by teachers in carrying out teaching and learning activities. This is in line with Piaget's theory which believes that intellectual development occurs when individuals face new challenges and experiences.

These results are also in line with research conducted by Virginia Ika Dani Nurgiyantari (2018) which states that the inquiry learning model can improve learning outcomes in terms of cognitive, affective, and psychomotor 
aspects. The achievement of cognitive aspect learning outcomes in the first cycle was $74.3 \%$ and increased in the second cycle by $77.8 \%$. The achievement of affective learning outcomes in the first cycle was $83.3 \%$ and increased in the second cycle by $86.1 \%$. Psychomotor achievement in the first cycle was $88.9 \%$ and increased in the second cycle by $97.2 \%$.

\section{e) Students' Interest in Learning}

Based on the results of the data analysis of the students' interest in learning scale in the control class and the experimental class, it shows that there are three categories of achievement of students' interest in learning based on the categories set out in Chapter III.

According to M. Buchori (1999:135) the notion of interest is a person's awareness that an object, person, problem or situation has something to do with him. So interest must be seen as a conscious response, otherwise it has no meaning at all.

In the control class, all indicators are in the category of high learning interest. Likewise with the experimental class where all indicators are in the category of high learning interest

For more details about the average percentage of students' interest in learning scores for each indicator in the control class and experimental class, it can be seen in Figure 1. below.

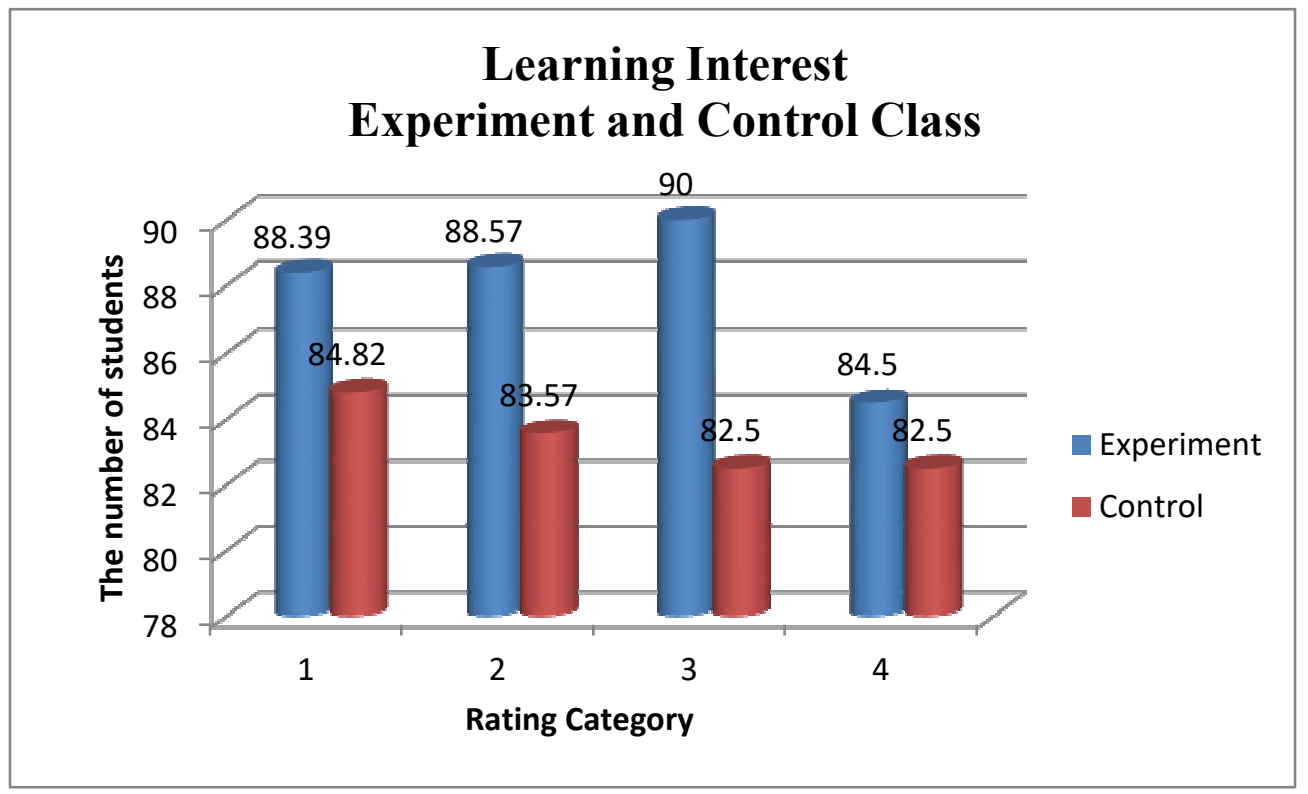

Figure 1. Learning Interest in Experiment and Control Class

From the figure, it can be seen that the average score in the experimental class is better than the control class. There are significant differences between the two classes.

Then based on questionnaires and interviews from several students, it is known that students tend to only accept the material provided by the teacher without wanting to look for other reading sources because facilities in schools such as libraries also do not support students in the learning process. When they have free time, students usually spend their time going elsewhere instead of taking advantage of their break in the library to read.

These results are in line with research conducted by Theodora Sinaga (2010) regarding the application of the Inquiry Learning Strategy to increase students' interest in learning. The findings of the study indicate that the application of inquiry learning can increase students' interest in learning. to the performed cycle. Starting from the first cycle the percentage is $56.67 \%$ until the fourth cycle reaches $83.33 \%$.

\section{CONCLUSION}

1. There are differences in learning outcomes between students who are given the inquiry learning model and students who are given direct learning on high learning interest.

2. There are differences in learning outcomes between students who are given the inquiry learning model and students who are given direct learning with low learning interest.

3. There is an interaction between the inquiry learning model and direct learning with interest in learning that is applied simultaneously affecting learning outcomes.

\section{ACKNOWLEDGMENTS}

The authors thank the anonymous reviewers for their helpful suggestions and comments on the previous versions of this article. 


\section{REFERENCES}

Abdurrahman, M. (2009). Pendidikan Bagi Anak Berkesulitan Belajar. Jakarta: Rineka Cipta

Agustina, N. 2011. Media dan Pembelajaran. Palembang: Universitas Sriwijaya.

Alni, Rahmawati, dkk., 2014, Statistika Teori dan Praktek, Edisi II. Universitas Muhammadiyah Yogyakarta, Yogyakarta.

Atun, 1. (2006). Pembelajaran Matematika dengan Strategi Kooperatif Tipe STAD Untuk Meningkatkan Kemampuan Pemecahan Masalah dan Komunikasi Siswa SMA. Tesis pada PPS UPI Bandung: Tidak diterbitkan

Gulo, W. 2002. Metode Penelitian. Jakarta: PT. Grasindo.

Hamalik, Oemar, 2005. Strategi Belajar Mengajar Berdasarkan CBSA. Bandung :SinarBaru.

Hamdayana, Jumanta. (2016). Metodologi Pengajaran. Jakarta : PT Bumi Aksara

Hasratuddin. 2018. Mengapa Harus Belajar Matematika?. Medan: Penerbit Perdana Publishing.

Sund \& Trowbridge. 1973. Teaching Science by Inquiry in the Secondary School. Columbus: Charles E. Merill Publishing Company.

Eviliasani, Hendriana And Sanjayawati. 2018. Analisis Kemampuan Berpikir Kreatif Matematis Ditinjau Dari Kepercayaan Diri Siswa Smp Kelas Viii Di Kota Cimahi Pada Materi Bangun Datar Segi Empat. Jurnal Pembelajaran Matematika Inovatif. Vol 1, No 3 (2018).

M. Buchori, 1999. Psikologi Pendidikan, Jakarta: Rineka Cipta. Witherington, Educational Psychology diterj. oleh M. Buchari: Psikologi Pendidikan

Dahar, R.W. 1991. Teori-teori Belajar. Jakarta: Erlangga.

Normaya. Karim. 2015. Ketuntasan Hasil Belajar Melalui Pendekatan Realistic Mathematics Education (RME). Jurnal Ilmiah Didaktika, 13(2): 92 - 104

Sanjaya, W. 2006. Strategi Pembelajaran. Jakarta: Kencana Prenada Media Group.

Shalahuddin, Mahfud. 1990. Pengantar Psikologi Pendidikan. Surabaya : Bina Ilmu

Usman, Moh. Uzer. 2005.Menjadi Guru Profesional. Bandung: Remaja Rosdakarya.

B. Weil, Joyce and Calhoun. 2000. Models Of Teaching. Newyork: A Person Education Company. 